\title{
Driver of Peace? Ping-Pong Diplomacy on The Korean Peninsula
}

Brian Bridges*

\section{Introduction}

"Table tennis has had a long history as a driver of peace, and we are happy to open a new chapter of table tennis diplomacy to promote peace on the Korean peninsula." With these dramatic words, Thomas Weikert, President of the International Table Tennis Federation (ITTF), welcomed news of a joint Korean women's doubles team being created in July 2018. ${ }^{1}$ Weikert has certainly not been alone in depicting sport as a positive force that brings together and even unites peoples and countries. The Olympic movement, indeed, was grounded in the beliefs of its founder Baron Pierre de Coubertin that sport would support and promote peace and friendship amongst peoples and countries. This idealism has continued to prevail within the Olympics and across a range of other global sports. But irrespective of the degree of justification for this idealism, there is little doubt that sport has become a major element of global socie-

* Affiliate Fellow, Centre for Asian Pacific Studies, Lingnan University, Hong Kong and Honorary Professor, Department of Social Sciences, The Education University of Hong Kong.

1 ITTF, "North \& South Korea to Join Forces at ITTF Korea Open," Press Release of International Table Tennis Federation, July 16, 2018. https://www.ittf.com/201 8/07/16/north-south-korea-join-forces-ittf-korea-open. 
ty and culture. The modern social history of any country cannot be fully understood without acknowledging the place of sport.

Conversely, a country's sporting history and development cannot ignore the role of politics. But, the interaction of sport with a nation's political history - and a nation's relationships with external powers - is complex. Domestically, sport provides a political resource that governments, political parties and interested groups utilize for a variety of policy objectives. Sport can improve people's health and well-being, create jobs and business activities, forge social cohesion, enhance nation-building and national identity, and serve as a distraction from policy difficulties. ${ }^{2}$ Sport contributes to social change, but occasionally can act as catalyst for political change, as happened, for example, in the case of South Korea (Republic of Korea) in 1987-88 when the democratization process was influenced by the imminent hosting of the 1988 Seoul Olympics. ${ }^{3}$

In recent years, academic sports studies increasingly have picked up "sports diplomacy" as one instrument in a country's diplomatic outreach - an example of "soft power." Therefore, externally, sport has been depicted as contributing to improving international relations by promoting interactions and reconciliation and even preventing conflict. In this context, sport can be a mediating factor through providing opportunities for leaders to meet informally at sporting events, acting as a bridge over cultural and linguistic differences, giving insights into other countries' society and acting as a platform for new agreements in other fields. ${ }^{4}$ Yet, the other side of the coin is that sporting contests can frequently take on the appearance of surrogate wars, with violence on and off the field of play,

2 Grant Jarvie, Sport, Culture and Society: An Introduction (London: Routledge 2006).

3 Brian Bridges, The Two Koreas and the Politics of Global Sport (Leiden: BrillGlobal Oriental, 2012), 66-78.

4 Judith Trankos and Bob Heere, "Sport Diplomacy: A Review Of How Sports Can Be Used To Improve International Relationships," in Case Studies in Sport Diplomacy, eds. Craig Esherick and Robert E. Baker (Morgantown,WV: FiT Publishing 2017), 1-15. 
which actually "accentuate inter-national dissonance."5

During the Cold War era, the ideological confrontation between the two superpowers, the United States and the Soviet Union, may not have descended into direct military engagement, but it was fought out fiercely in a number of other dimensions, including cultural and sporting arenas. Sports competitions therefore often became high profile events through which the "respective merits of the competing social and political system, ideologies and moral orders were contested in symbolic combat." 6 Against this global Cold War background, the cases of ideologically divided societies or divided countries can be seen to further reinforce the positive and negative roles for sport. Sport can be utilized as the "first step," one means for promoting contacts and peaceful exchange between the two "part-nations," and in the event of eventual unification, act as a force for consolidating socio-political unity. However, the very fact that these two political entities are usually involved in a highly-charged competition for legitimacy means that sports tournaments and even sporting exchanges can become arenas for nationalistic posturing and political manoeuvring. ${ }^{7}$ These contradictions have been found in the cases of the two Germanies (1945-90), China and Taiwan (1949 to the present) and, of course, the two Koreas.

The argument advanced here is two-fold: that the characteristics of the politics-sport nexus in the Korean case ensures that politics dominate sporting interactions in inter-Korean relations, and that the "mythology" that has arisen over the efficacy of using table tennis as a medium of po-

5 Paul Close, David Askew and Xu Xin, The Beijing Olympiad: The Political Economy of a Sporting Mega-Event (Abingdon: Routledge, 2007) 54-5. George Orwell famously described sport as "war minus the shooting". Cited in Victor D. Cha, Beyond the Final Score: The Politics of Sport in Asia (New York: Columbia University Press. 2009), 8.

6 Stephen Wagg and David L. Andrews, East plays West: Sport and the Cold War (London: Routledge 2009), 4.

7 John Sugden and Alan Bairner, eds, Sport in Divided Societies (Oxford: Meyer and Meyer, 1999). 
litical reconciliation has proved misplaced in the Korean case. Therefore, this article examines the extent to which sport plays positive or negative roles in inter-Korean relations by analyzing the limited attempts to recreate "ping-pong diplomacy" on the Korean peninsula. Unpublished British and American archives provide new light on the details of such sporting diplomacy.

\section{The Sino-American Precedent}

The term "ping-pong diplomacy" originates from the way in which interactions between table tennis players from the United States and the People's Republic of China (PRC) in the early 1970s opened a window of opportunity for establishing political connections between the two previously antagonistic states, which at that time did not recognize each other diplomatically. Both the US and PRC national teams participated in the $31^{\text {st }}$ World Table Tennis Championships, organised by the ITTF and held in Nagoya, Japan, in March-April 1971. The US team was to be wellbeaten by its stronger Asian opponents, but after one training session Glenn Cowan, a US team member, missed his own team bus going to the match arena and jumped on the next available one, which happened to be the Chinese team bus. Zhuang Zedong, the PRC team captain, overcame his teammates' reservations to talk with him. Their friendly chat led to an exchange of souvenirs and an unofficial request by the Americans to visit China after the tournament had finished. After some deliberation, PRC leader Mao Zedong agreed to issue a formal invitation and so the US table tennis team made the historic visit to China in April, $1971 .^{8}$

The first American sportsmen to visit the PRC since the 1949 Revolution, the US table tennis team visited the Great Wall and the Peking Opera, met with PRC Premier Zhou Enlai and generally created much

8 Nicholas Griffin, Ping-Pong Diplomacy: The Secret History Behind the Game That Changed the World (London: Simon \& Schuster, 2014). 
publicity within China and globally for what was seen as an important breakthrough in US-PRC relations. As Zhou later remarked: "a ball bounced over the net and the whole world was shocked." ${ }^{9}$ During the visit, US President Richard Nixon announced a relaxation of the US embargo on China while applauding the historic visit. However, behind the scenes, Nixon had already made a strategic decision to initiate some secret contacts between his officials and their PRC counter-parts the previous year, while the Chinese side too had been deliberating on when and how to open up connections to the United States. Thus, though unexpected, the ping-pong team visit was timely and helped push forward the momentum of the secret diplomacy that might otherwise have stalled. This eventually led to Nixon's historic visit to Beijing in February 1972. So, table tennis facilitated but did not alone create the opportunity. As Victor Cha observes, "Sport was a necessary but not sufficient condition for the breakthrough." 10

Nonetheless, the mythologized image of "ping-pong diplomacy" as having a particular capability to improve inter-national relations has remained strong. The same China Daily report that commemorated 30 years of Sino-American relations by highlighting the impact of that ping-pong diplomacy actually ended with a brief reference to the role of table tennis in improving North-South Korean relations in 1991 and how it "might lead the split Korea to reconciliation and reunification."11

Why table tennis? The game itself dates back to the 1880 s when it began as a winter diversion, using a dining table for lawn tennis players in the United Kingdom. From there it spread across Europe and then globally. Although World Championships began in 1926, it was only after the Second World War that the sport became regularized with biennial world championships (after 2000 biennially with team championships in evennumbered years and individual championships on odd-numbered years).

9 China Daily, January 7, 2009.

10 Cha, Beyond the Final Score, 79.

11 China Daily, January 7, 2009. 
Table tennis is a fast-paced but relatively accessible sport, open to all ages and types of athletes, with simple equipment and facilities. In the second half of the twentieth century it became extremely popular in East Asia, where space and time for sporting activity is often at a premium. So, it perhaps is not surprising that the various attempts to use table tennis for diplomatic objectives invariably involve one side, if not both sides, coming from Asia.

Although some Western missionaries had tried to introduce table tennis to Korea at the end of the nineteenth century, it had not become an established sport by the time the Japanese occupation began in 1910. Under Japanese control, Korean sport became increasingly militarized and focused on physical education and martial arts. ${ }^{12}$ Table tennis, therefore, only began to revive after the defeat of Japan in 1945 or, to be more accurate, after the end of the Korean War in 1953. Although the politicallydivided peninsula meant that different political and social-economic ideologies and sport policies emerged, ironically, from the 1960s they did share a common objective: utilizing sport for "national" success in various international arenas as a means of marking not just sporting achievement but ideological supremacy. ${ }^{13}$ Table tennis, which became increasingly popular in both Koreas from the 1960s, was to become one such symbolic field of the North-South "sports war."

Although South Korea (Republic of Korea) joined the ITTF in 1950, the development of table tennis, as with many other sports in South Korea owed much to the new sports policies introduced under President Park Chung-hee, who believed that Korea's regeneration required physical as well as economic and military strength. Consequently, from the mid1960s considerable governmental resources were poured into cultivating elite athletes capable of winning in international competitions. Table tennis was no exception.

12 Ok Kwang, The Transformation of Modern Korean Sport: Imperialism, Nationalism, Globalization (Seoul: Hollym, 2007), 200-296.

13 Ok, Transformation, 316. 
In North Korea (Democratic People's Republic of Korea) too, table tennis began to be seen as one sport in which their athletes could excel, and it joined the ITTF in March 1957. President Kim Ilsŏng, in congratulating Pak Yongsun on becoming the first North Korean ever to win the women's singles World Championship in Calcutta in 1975, expounded on his own realization of the sport's potential. He recalled a childhood experience in the 1920s when he visited several middle schools in Pyongyang, but "none of them had any table tennis facilities." Yet, while in exile in Jilin province, China, he became aware of how popular table tennis was there; "there were several table tennis tables for each class" in his high school. Later, therefore, Kim was to order the construction of all-weather concrete table tennis tables across the country and the setting up of hundreds of table tennis clubs. Kim praised "sports heroine" Pak, who "was fighting with a strong will and a stubborn fighting spirit, attacking to the last shot just as the anti-Japanese guerrillas did," then used her example as a model to urge the further development of table tennis and the creation of a "kingdom of sports."14 Pak won gold again at the 1977 World Championships in Birmingham and was expected to continue to do well at the 1979 Championships, which were to be held in Pyongyang itself.

\section{0s Origins of Korean Ping-Pong Diplomacy}

After the vicious but ultimately stalemated Korean War, the two Koreas settled into a bitter competitive rivalry with minimal contact with the other side. However, the end of the 1960s and the beginning of the 1970s were to be characterised by significant changes in the international system, most notably the emerging rapprochement between China and the United States, which had been stimulated by "ping-pong diplomacy." Despite their strong dislike and distrust of each other, the two Koreas feared being

14 Kim Ilsŏng, Kim Il Sung: Works, Volume 30 (January-December 1975 (Pyongyang: Foreign Languages Publishing House, 1987). 
dominated by the new order emerging and so were pushed into bilateral talks that culminated in the historic North-South agreement on July 4, 1972 that set out various principles for peaceful and independent reunification as well as a pledge to carry out "various exchanges in many fields" so as to "restore severed ties, promote mutual understanding and to expedite independent peaceful unification."15 Discussions between the lead South Korean negotiator and North Korean leader Kim Ilsŏng made it clear that creating a unified team for future Olympic participation could be one such exchange. ${ }^{16}$ However, the 1972 political understandings proved fragile as working-level meetings deteriorated into mutual vilification, while sporting cooperation proved equally elusive. Reviewing the intra-Korean interactions and dialogues of the 1960s and 1970s, retired diplomat Ralph Clough argued that the South Koreans "suspected all their [North Korean] proposals for dialogue to be smoke screens behind which they were preparing a military attack", while the North Koreans "saw South Korean proposals as devices to prolong the division of Korea." 17

Sports organizations and facilities in South Korea had developed to the stage that it could host some international competitions, but, under pressure from the North, communist country athletes did not participate, even though the South amended its anti-communist legislation in the early 1970 s to allow for their entry if essential for friendly international relations. Equally constrained was the situation of South Korea's athletes participating in sporting events in socialist states with which it did not have diplomatic relations. The first breakthrough in this respect was the participation of South Korean student athletes in the 1973 Universiade (World University Games) in Moscow, which North Korea then boycotted in

15 Koh Byungchul, "Unification Policy and North-South Relations," in North Korea Today: Strategic and Domestic Issues, eds. Robert A. Scalapino and Kim Junyeop (Berkeley: University of California 1983), 278-83.

16 Bridges, Two Koreas, 59-60.

17 Ralph Clough, Embattled Korea: The Rivalry for International Support (Boulder: Westview Press, 1987), 118. 
protest. Nevertheless, sporting contacts with other socialist states that were hosting international sporting events slowly began to increase during the 1970 s. ${ }^{18}$

However, South Korean athletes joining international sporting events in North Korea remained impossible. This issue came to a head in 1979 at the $35^{\text {th }}$ World Table Tennis Championships (WTTC), which for the first time were held in Pyongyang in April-May 1979. The hosting by North Korea had earlier been approved by the ITTF members by a large majority after the North "had given assurances that all member countries of the ITTF would be allowed to participate in accordance with ITTF regulations." 19

In January 1979 South Korean President Park called for a renewal of inter-Korean dialogue, anytime, anywhere. This had prompted various counterproposals from the North Koreans. On 20 February they proposed a joint North-South Korean table tennis team for the Pyongyang championships. South Korea had already submitted an independent application through ITTF for visas to Pyongyang, but the North wanted to put the emphasis on a joint team. However, four rounds of talks at the Panmunjom border between the two national table tennis associations from late February to mid-March only resulted in deadlock. ${ }^{20}$ For example, US diplomats later summarized the 9 March meeting as an "inconclusive and occasionally acrimonious three hours." 21 A British diplomat stationed in Seoul, who had spoken directly to one member of the South Korean negotiating team several times, concluded pessimistically a few days later that

18 Bridges, Two Koreas, 61.

19 The National Archives, United Kingdom (hereafter TNA): Memorandum by Thorold Masefield, Far Eastern Department, Foreign and Commonwealth Office (FCO), April 19, 1979, FCO21/1762.

20 Korea Newsreview, March 3, March 10, March 17,1979; National Unification Board, A White Paper on South-North Dialogue in Korea (Seoul, 1982), 167-74.

21 National Archives and Record Administration (hereafter NARA), United States, Department of State Electronic Telegrams: US Ambassador in Seoul William Gleysteen to State Department, March 9, 1979. 
despite multiple meetings "there are very few signs of a genuine thaw" and that as a result South Korea's chances of participating in the championships "appear to be negligible."22

Given that the ITTF had planned to carry out the draw for the championships on 14 and 15 March, the time available to select players, arrange joint training, and settle multiple logistical issues was very limited. Moreover, the South Korean side felt that the first priority was to ensure that their earlier application for visas to enter the North should be guaranteed (the North initially claimed that it had never received these applications). The North counter-proposed that the South's players would be given visas if the South first signed an agreement committing to a single team. ${ }^{23}$ In the view of one British diplomat the deadlock occurred "because the South Koreans believed a joint team would be impractical, and because the North Koreans refused to give an assurance that a separate South Korean would be admitted to North Korea". His assessment was that "the North's tactics were designed to find a means of denying the ROK team entry while making it appear the result of the South's unreasonableness." 24

The South Korean players were expected to undertake preliminary training and matches in Scotland and West Germany before returning to South Korea in late March and then to prepare to fly to Geneva on 18 April. The team - five men and five women players plus officials - did fly to Geneva on that date and then spent a frustrating three hours at Geneva airport waiting in vain to get visas so as to board one of the two special charter flights sent by the North to ferry foreign athletes to Pyongyang via Moscow. With no visas granted, the team had no alternative but to give up and to fly back to Seoul. ${ }^{25}$

22 TNA: Warwick Morris, UK Embassy in Seoul, to Paul Whiteway, Far Eastern Department, FCO, March 12, 1979, FCO21/1762.

23 NARA: Gleysteen to State Department, March 12,1979.

24 TNA: Memorandum by Masefield, April 19,1979, FCO21/1762.

25 Korea Newsreview, April 28, 1979. 
A Western journalist who watched the championships noted that "the staging of the table tennis events progressed with some normality" in contrast to the "sessions of doctrinal conditioning" outside the stadium. The stadium was packed every evening with Korean spectators, who "applauded vociferously as each Korean player won a point and hissed loudly when an opponent scored." Pak Yong Sun was eliminated at the quarterfinal stage but the new North Korean star of the women's singles, Li Song Suk, reached the final. Unfortunately, despite winning the first game, Li lost out to her Chinese opponent. As the despondent Li left the arena, "the entire crowd rose quickly and evenly to its feet and vacated the stadium," without waiting to watch the men's final in which no North Korean was participating. ${ }^{26}$

In the view of Albert Shipley, who as the President of the English Table Tennis Association (ETTA) attended the championships in Pyongyang, "it was clear that the table tennis itself was less important to the North Koreans than the propaganda advantage of hosting the world championships." 27 The South Koreans naturally were bitter about their exclusion. A senior South Korean Foreign Ministry official complained to the British Ambassador in Seoul that "the President of the ITTF seemed to be naïve, understanding nothing of the political significance and interested in retaining his current position for life." ${ }^{28}$ According to Shipley, however, Roy Evans, the Welshman who was ITTF President, wanted above all to avert a split within the ITTF over the issue of excluding South Korea (and Israel) and so, although 17 member associations signed a protest note and a few national table tennis associations toyed with the idea of boycotting the tournament, Evans went with the much larger ma-

26 Lewis, Richard, "North Korea's Behaviour At The 1979 Ping Pong Championships Really Said It All," Business Insider May 12, 2014, https://www.businessinsider.co $\mathrm{m} /$ ping-pong-in-north-korea-2014_5?IR=T.

27 TNA: Note by Whiteway, May 11, 1979, FCO21/1762.

28 TNA: Telegram from Morris to FCO, April 23, 1979, FCO21/1762. 
jority of members in accepting the North Korean actions as host. ${ }^{29} \mathrm{~A}$ sceptical US diplomat commented that Evans and the ITTF had "caved in" to North Korean pressure. ${ }^{30}$

Indeed, in the view of another observer of the tournament, the North Koreans were concerned not so much about the South Koreans as about the American participation, evidently hoping that there might be opportunities, along the lines of the much-touted "ping-pong diplomacy" between China and the United States earlier in the decade, to develop contacts with the United States through the attending American athletes, officials and reporters. ${ }^{31}$ The United States did in fact send a large delegation of 40 players and officials in what was to be the first ever US sports delegation sent to North Korea. The North toned down its usual anti-US propaganda and initially treated the Americans with kid gloves, although halfway through the tournament mandatory "guides" were attached to any players going outside. The US delegation did not include anyone with political responsibilities, a fact which presumably the North Koreans noted, so that meant that although the delegation head did chat with North Korean VicePresident Pak Song Chol [Pak Sŏngch'ŏl] for half-an-hour at a reception neither on that occasion or in any other situation were there "perceived efforts to pass (a) message to (the) U.S." 32 North Korean officials therefore resorted to giving interviews to the few accompanying US journalists. ${ }^{33}$ Consequently, whatever may have been North Korean aspirations before the tournament began, the US Government, which was unhappy at the exclusion of the players of two countries with which it had particularly strong ties, concluded afterwards that the events surrounding the ITTF

29 TNA: Foreign Office Memorandum, August 1, 1979, FCO 21/1762. According to Shipley, the names of the South Korean players had actually been included in the tournament programme distributed to the participants.

30 NARA: Memorandum by US Secretary of State Cyrus Vance, May 15, 1979.

31 Bradley Martin, Under the Loving Care of the Fatherly Leader: North Korea and the Kim Dynasty (New York: Thomas Dunne Books, 2004), 139-42.

32 NARA: Memorandum by Vance, May 15,1979.

33 Martin, Under the Loving Care, 150-7. 
championships "contributed neither to the North-South dialogue nor to the larger issue of the lessening of tensions on the peninsula." 34

US President Jimmy Carter had come into office pledging to withdraw US troops from South Korea; a policy that was confirmed in late 1978 even though "reduce" replaced "withdraw" in the diplomatic lexicon. Only in June 1979 did Carter tell the South Koreans that he was going to reverse course, because of new intelligence analyses, and suspend all troop withdrawals. ${ }^{35}$ At the time of the ITTF tournament North Korea must have still been hoping that Carter would continue with troop reductions; a softer line towards the United States then seemed logical but the determination to disadvantage the South by exclusion from the tournament must have over-ridden such imperatives. Therefore, ping-pong diplomacy, whether with South Korea or with the United States, did not take off on this occasion.

In addition, the failed North-South Korean negotiations and what was perceived internationally as North Korean intransigence and backtracking on promises had two results which were to be counter-productive for the North. Firstly, many international sporting federations became wary of the North, which for decades was not again asked to host a major international sporting event. Secondly, during the 1980s, socialist allies of the North slowly became more willing to send their athletes to international sporting competitions in the South. ${ }^{36}$

\section{The 1991 Breakthrough}

During the 1980 s there were signs of increased sporting activity in the North through participation - and success - in international sports competitions. In 1985 ,

34 NARA: Memorandum by Vance, May 15,1979.

35 Lee Chaejin and Sato Hideo, U.S. Policy Toward Japan and Korea: A Changing Influence Relationship (New York: Praeger, 1982), 104-27.

36 Clough, Embattled Korea, 318-20. 
at the time of both the North Korean men's and women's table tennis teams defeating their respective southern counterparts in the $38^{\text {th }}$ World Table Tennis Championships held in Sweden, a North Korean sporting official revealed that table tennis had been designated a "strategic sport" with over 100,000 players competing annually in regional and national championships in order to be chosen for the national teams. ${ }^{37}$

In one of the longest policy statements ever made public about sports development in the North, in May 1986, Kim Chŏngil gave his frank assessment both on the "big strides" that had been made in popularizing physical education and sports and on the tasks ahead. ${ }^{38}$ For Kim, sports and physical education clearly had functional roles: they "contribute to the wealth and development of the country, a strong national defense, the people's health and national prosperity. .......[and also] bring honor to the country and promote friendly relations with many countries." As such, sport was "decisive to the destiny of the country and the nation." After extolling the virtues of physical education and sport, Kim went on to give advice to various sectors of society: physical education at schools should be "intensified" because it would stimulate "the growth in stature of the pupils" and teach them "at least one sporting skill"; the quality of school sports training should be improved by more responsible teachers; enterprises and cooperative farms should organise and set aside times for exercise and games; more sports facilities should be built in provincial cities and towns; the Korean Workers Party's organizations should take charge of organizing physical training for workers; "scientific standards" should be used for selecting sportsmen and women for each event in international competitions; television programs and newspapers should highlight distinguished sports personalities and special diets should be constructed to help athletes' bodies develop ("a lot of meat, oil, many eggs and plenty of chocolate").

At both the domestic and international levels, the 1988 Seoul Olympics provided definite and broadly positive legacies for South Korea. Although through the active participation of most of the socialist allies of North Korea, the Seoul Olym-

37 Clough, Embattled Korea, 321.

38 Kim Chŏngil, "On Popularizing Physical Training and Sport and Developing Sporting Skills Rapidly,” May 19, 1986. www.korea-dpr.com. 
pics showed it was possible for South Korea to work with countries of differing ideologies, the Olympics - or, at least the run up to them - did nothing to improve North-South relations. Tortuous negotiations in response to the North's demands for co-hosting were carried on for over three years before ending in failure and the North's boycott of the event. ${ }^{39}$ Ironically, the Seoul Olympics was the first time that table-tennis was included as an Olympic sport.

The dramatic events in Eastern Europe in 1989 presaged another significant change in the international environment and, as in 1971, spurred the two Koreas into talking with each other again. After diplomatic fencing for most of 1990, in September that year the two sides began prime-ministerial level meetings for the first time. Intermittent meetings during 1990-91 led to the two Koreas making their entry into the United Nations (UN) and the signing of an unprecedented bilateral Agreement on Reconciliation, Non-aggression, Cooperation and Exchange. ${ }^{40}$

In parallel with the mood of inter-Korean reconciliation in 1990-91, however, sporting contacts too achieved a breakthrough. According to data from the South Korean National Unification Board, between 1988 and 1992 representatives of the two governments or related organizations met 160 times, of which 23 were related to sports exchanges. ${ }^{41}$ Several frustrating rounds of talks about forming a joint Korean team for the 1990 Beijing Asian Games were held in late 1989-early 1990, but both sides accused the other of making "unjust demands" and the talks finally broke down over the North's demand that the South basically agree to send a joint team or none at all, which upset the South. ${ }^{42}$ However, an informal joint "cheering team" was created and, more importantly, the Asian Games provided a venue

39 Richard Pound, Five Rings Over Korea: The Secret Negotiations Behind the 1988 Olympic Games in Seoul (Boston: Little, Brown \& Co, 1994).

40 Aidan Foster-Carter, Korea's Coming Reunification: another East Asian superpower? (London: Economist Intelligence Unit, 1992), 55-7,82-3.

41 Oh Kongdan, "The Problem and Promise of Inter-Korean Economic Cooperation," in Korea Briefing: Toward Reunification, ed. David R. McCann (New York: M.E. Sharpe, 1997), 28.

42 Adrian Buzo, The Guerrilla Dynasty: Politics and Leadership in North Korea (Boulder: Westview Press, 1999), 181,277. 
for informal meetings between North Korean Vice-President Li Jongok and Park Ch'ul Un, an influential political fixer close to then South Korean President Roh Tae Woo, as well as between sports ministers from the two sides. Consequently, in October 1990 the South Korean sports minister visited Pyongyang and his counterpart visited Seoul while two North-South Reunification Soccer Matches were played in Pyongyang and Seoul. These matches in a sense were reviving what had been the pre-1945 tradition of soccer matches between those two cities, only now between two countries. ${ }^{43}$ Fortuitously or otherwise, the North won the first game in Pyongyang and the South won the return match in Seoul. This in turn led on to decisions on arranging selection matches and joint training for the creation of joint teams in 1991 for the $41^{\text {st }}$ WTTC in Chiba, Japan, and the 6th Junior World Football Championships held in Portugal. ${ }^{44}$

January and February 1991 saw multiple rounds of negotiations (later said to have totalled 22 rounds) for the first event, the table-tennis teams for the WTTC in late April- early May. After concessions coming mostly from the South, it was agreed that joint training would take place in Japan (neither side would agree to use their counter-part's territory), the teams would be selected through joint competitions, the flag would become the united Korea design in blue on a white background, for the anthem the traditional folk-song Arirang would be used, and that the Korean table tennis delegation would be headed by a North Korean while a South Korean would head up the later football squad. ${ }^{45}$ The joint teams performed creditably, with Li Bun Hui, from the North, gaining silver in the wom-

43 Annual football matches between Seoul and Pyongyang (Kyŭng-P'yŏng) were held from 1929 through most of the 1930s. Ok, Transformation, 330. See also Lee Seok, "Becoming a Member of the Japanese National Football Team as a Korean: The 1936 Berlin Olympic Trials and Colonial Korea," in Sport in Korea: History, Development, Management, eds. Kwak DaeHee, Ko Yongjae, Kang Inkyu, and Mark Rosentraub (London: Routledge, 2017), 31-44.

44 Foster-Carter, Korea's Coming Reunification, 36, 54; Jhe Seongho, "North-South Sports Exchange and Peace on the Korean Peninsula," in Peace on the Korean Peninsula through Sports Exchange (Seoul: Sports Institute of National Unification, 2003), 162-3.

45 Korea Newsreview, February 23, 1991. 
en's singles. ${ }^{46}$ But, the most dramatic match was in the final of the Corbillon Cup women's team event, resulting in the unified Korean women's team defeating the strong Chinese team to win the women's championships. The Chinese women's team had won the eight previous team championships in succession. Yonhap News Agency's later report exulted the fact that this joint team was successful in "knocking the previously invincible Chinese team off their pedestal." 47 Chang Ung, Secretary-General of the North Korean National Olympic Committee, emotionally described this victory as "the biggest moment ever for our divided nation," while one foreign observer living in Pyongyang at the time noted that "the victory was greeted with delirium by the people of North Korea." ${ }^{48}$ The symbolism of this particular victory has remained strong on both sides of the border and has been referred to frequently over the subsequent decades. It was further immortalized in the South Korean film "Koria" ("As One" in English), released in 2012. The director of that film later explained that, "I thought the only beautiful event in North-South relations was the story of those athletes." 49

Nevertheless, the joint teams were the result of "government contacts rather than purely civilian exchanges" and little in the way of real sporting exchanges followed; they became one-off events. ${ }^{50}$ They also proved costly from the South Korean perspective in that the South bore all the expenses: 164 million won for

46 Twenty years later Li recalled her experiences of partnering South Korean Hyun Junghwa in the doubles: "For 50 days, 24 hours a day, we lived together as one, trained together, slept in the same room and ate all our meals together. We shared the same food - and our feelings." Jean H. Lee, "Ex-NKorean star recalls "ping pong diplomacy'," San Diego Union-Tribune, July 12, 2012, www.sandiegouniont ribune.com/sdut-ex-nkorean-start-rcealls-ping-pomg-diplomacy-2012jul12-storyhtml.

47 Yonhap News Agency, Korea Annual 1992, 267. Seoul, 1992.

48 Korea Newsreview, May 4, 1991; Michael Harrold, Comrades and Strangers: Behind the Closed Doors of North Korea (Chichester: John Wiley \& Sons, 2004), 274.

49 Kosuke Takahashi, "When ping-pong diplomacy stirred Korea," Asia Times. May 17, 2012. http://www.asiatimes.com/asiatimes/Korea /NE09Dg01.html.

50 Gabriel Jonsson, Towards Korean Reconciliation: Socio-Cultural Exchanges and Cooperation (Aldershot: Ashgate, 2006), 119-20. 
the WTTC and 786 million won for the football participation. ${ }^{51}$ Moreover, the North was not above using this cooperation to make another political point in the context of the South's mounting campaign for UN membership, arguing in April 1991 that the South was being "splittist" on the UN membership issue in contrast to its sporting agreements on a single name, team, and other logistical aspects. ${ }^{52}$ Although it is not clear how reliable were rumors that the North Korean players and staff suffered from being "too impressed" by the liberal thoughts and lifestyle of their southern counterparts, it was the defection to South Korea, via Spain, of a well-known North Korean judoka, who had been a silver medallist at the 1990 Asian Games, in August 1991 that effectively brought to an end any further discussions about joint teams, specifically for the 1992 Barcelona Olympics, as the North suspended the talks in retaliation. ${ }^{53}$

Earlier in 1991 President Roh's unofficial emissary Park Ch'ul Un had elaborated on his vision of sports exchanges with the North, which he anticipated would consist of three stages: creation of a single delegation for the 1992 Olympics, a sports exchange treaty, and finally a merging of the two NOCs. ${ }^{54}$ Although the December 1991 North-South Agreement did include a brief reference to sports, there was not a separate, specific agreement solely for sports and in reality not even the initial stage of Park's ideal plan - a joint team at Barcelona - could be achieved. As North-South political relations again became tetchy in early 1992, so the dream of a joint team for the Barcelona Olympics faded away.

\section{PyeongChang and Beyond}

The 1990s, indeed, were to see almost no contacts between the two Koreas on

51 Choi Daeseok. "Building Bridges: The Significance of Inter-Korean Sports and Cultural Exchange," East Asian Review, 14, no.4 (Winter 2002): 113.

52 Shinn RinnSup, "North Korea: Squaring Reality with Orthodoxy," in Korea Briefing, 1991, ed. Donald Clark (Boulder: Westview Press, 1991), 119-20.

53 Bridges, Two Koreas, 88.

54 Korea Newsreview, June 8, 1991. 
sporting matters, not least because of rising tensions in 1993-94 over the North Korean nuclear program and then the mid-1990s famine and humanitarian crisis in the North. Political relations and sporting relations remained cool. But the whole character of North-South relations appeared to change with the election of Kim Daejung as the South Korean president and his "sunshine policy" of opening up to the North. At the historic June 2000 summit between Kim Daejung and Kim Chŏngil in Pyongyang, the first ever such meeting between the leaders of the two states, they agreed on greater cooperation through the reuniting of families split by the Korean War, economic cooperation, the promotion of socio-cultural exchanges (sports was listed as one component of this aspect), and even intergovernmental discussions on reunification. ${ }^{55}$ After 1972 and 1991 this could be counted as the third "breakthrough" in North-South relations, but the fact that neither of those two earlier agreements had been fully implemented did not auger well for this latest agreement.

However, while euphoria reigned in the South, the political improvement did encourage sporting contacts too. In the month following the Pyongyang Summit, a "Reunification Table Tennis Tournament" between a Samsung Life Insurance team and the North's Moranbong team was held in Pyongyang. The first time for table tennis players to meet each other on Korean soil since 1948, this game, according to the North Korean media, "swelled the hearts of the fellow countrymen with a fresh confidence in reunification." 56 This tournament became the first ever sports event held in the North to be broadcast live on television in the South. ${ }^{57}$

But, more significantly, direct contacts between the two Korean NOCs were quickly instituted, agreement was reached within a month and at the September 2000 Sydney Summer Olympics opening ceremony the two Koreas made an emotional entry into the Olympic stadium under a joint flag even though they were

55 Don Oberdorfer, The Two Koreas: A Contemporary History (New York: Basic Books, 2001), 426-33; Son Key-young, South Korean Engagement Policies and North Korea: Identities, Norms and the Sunshine Policy (London: Routledge, 2006), 104-21.

56 Bridges, Two Koreas, 96.

57 Jhe, "North-South Sports," 164. 
then to go on to compete as separate teams. The newly established "tradition" of joint entry continued through subsequent Summer and Winter Olympics and Asian Games until 2006. ${ }^{58}$ However, North Korea's first nuclear test in late 2006 and the subsequent deterioration in inter-Korean relations meant that, despite Chinese encouragement, the joint entry failed to take place at the 2008 Beijing Olympics.

Thereafter, sporting contacts between the two sides remained almost nonexistent. In the South, successive presidents (Lee Myung-bak [Yi Myŏngbak] and Park Geun-hye [Pak Kŭnhye]) displayed caution and concern about the North's nuclear policies, while in the North the death of Kim Chŏngil and the succession of his son Kim Jŏnŭn was marked by little in the way of substantial policy change, even if the new young leader's style was different from his father's.

Despite the new leader's enthusiasm for basketball and his professed ambition to turn the North into a "sports power," Kim Jŏngŭn had little interest in developing inter-Korean sporting contacts. Indeed, Kim's focus on national sporting successes had echoes of the former East Germany's drive for a separate sporting identity that created a sports training regime that performed on an international stage significantly above expectations in the 1970s and 1980s and paradoxically drove it further away from sporting cooperation with West Germany. Politically, however, as Kim continued with missile and nuclear tests in the face of sustained and increasing UN sanctions, North Korea's relations with the United States and other interested powers became even more tense. Even the election of Moon Chaein, a convinced supporter of engagement with the North, as South Korean President in May 2017 brought no up-tick in inter-Korean relations. Rather, by the end of 2017 the atmosphere in and around the peninsula had sunk to a new low. With US President Donald Trump talking about using "fire and fury" against the North, the possibility of renewed military conflict on the peninsula seemed to be very real. ${ }^{59}$

Then, Kim Jŏngŭn decided to make a gesture towards the South by agreeing to

58 Bridges, Two Koreas, 95-107.

59 Stephen Noerper, "Tensions, Tests, and Drift," Comparative Connections, (January 2018): 33-40. http://cc.pacforum.org/2018/01/tensions-tests-drift 
send athletes - and a high-level delegation which included his sister - to the February 2018 Winter Olympics in PyeongChang, which had won the hosting bid at the third time of asking. ${ }^{60}$ Moreover, for the first time ever at the Olympics a united Korean team took part - the women's ice hockey team - though the results were rather disappointing. ${ }^{61}$ Although characterised as sporting cooperation for peace, Kim's calculated step was politically-loaded, neatly undercutting South Korea's intended narratives and garnering international media attention instead on North Korea's role. Originally focused on "new horizons" (expanding winter sports to Asia and the world), the PyeongChang Olympics suddenly became the "peace Olympics." ${ }^{2}$ This dramatic show, which nonetheless was warmly welcomed by both the IOC and South Korea, was to bring political benefits culminating in the first Moon and Kim summit meeting at Panmunjom in April 2018 and then a second such summit in September the same year in Pyongyang.

Table tennis, of course, could not be included in a Winter Olympic schedule, but the sport did contribute to the new mood of reconciliation. At the World Table Tennis Team Championships in Halmstad, Sweden, in May 2018, the two Korean women's teams made their way through to the quarter-finals, but when they walked onto the court they told the umpires that they did not wish to compete against each other, but rather to compete as a unified team in the next round, a semi-final. The heads of the two Korean table tennis associations had already met with ITTF president Weikert beforehand and received approval for this dramatic

60 Udo Merkel and Kim Misuk, "Third time lucky!?: Pyeongchang's bid to host the 2018 Winter Olympics - politics, policy and practice," International Journal of the History of Sport 28, no. 16 (November 2011): 2365-2383; Scott Snyder, "South Korea's Olympic Gains," Council on Foreign Relations Expert Brief January 26, 2018, https://www.cfr.org/expert-brief/south-koreas-olympic-gains.

61 For details see Seth Berkman, A Team of Their Own: How an International Sisterhood Made Olympic History (New York: Hanover Square Press, 2019).

62 Duncan Mackay, "Bach hails Pyeongchang 2018 for its part in Korean peace process and promises IOC will continue to play role," Inside the Games, February 7 , 2019, https://www.insidethegames.biz/articles/1075256/bach-hails-pyeongchang2018-for-its-part-in-Korean-peace-process-and-ptomises-ioc-will-continue-to-playrole. 
gesture. ${ }^{63}$ But, unlike 1991, there was no dream result, as the unified team (one North Korean and two South Koreans actually played) lost 0-3 to Japan in the semi-finals. However, although a unified Korean table tennis team re-appeared at the ITTF Korea Open in July 2018, since early 2019 the pace of political reconciliation has slowed considerably and despite the South raising proposals for joint sporting activities or mega-event hosting bids, once again the momentum has gone out of inter-Korean sporting cooperation. The 2020 ITTF World Team Championships, due to be held in Pusan, South Korea, and which could have acted as another site of sporting unification, have been postponed because of the Covid-19 virus outbreak and thereby another opportunity has been lost.

\section{Conclusion}

Politically divided nations have been particularly sensitive to issues of recognition, equality and image within global sporting communities. Under severe pressure from the IOC, the two Germanies did grudgingly cooperate at the Olympics from 1956 to 1964, but essentially operated as two separate entities both before that period and after until eventual reunification in 1990; sport provided very little traction for any political rapprochement. ${ }^{64}$ In the case of the PRC and Taiwan, still far from reunification, there has been little direct sporting contact and the political struggle over international sporting representation that raged for three decades (seemingly settled in 1979 with the PRC as a full Olympic member and Taiwan's membership contingent on using the title of Chinese Taipei ${ }^{65}$ ) remains

63 Michael Pavitt, "North and South Korea abandon quarter-final clash to form unified team at ITTF World Championships," Inside the Games, May 3, 2018, https://www.insidethegames.biz/articles/1064646/north-and-south-korea-abandonquarter-final-clash-to-form-unified-team-at-ittf-world-championships.

64 Manfred Lammer, "The Olympic Games: A Bridge to Unification? German Experience and Korean Perspectives," in Peace on the Korean Peninsula through Sports Exchange (Seoul: Sports Institute of National Unification, 2003), 99-111.

65 Xu Guoqi, Olympic Dreams: China and Sports, 1895-2008 (Cambridge: Harvard University Press, 2008), 96-114. 
rumbling beneath the surface and may well reappear in the run up to the 2022 Beijing Winter Olympics.

The Korean experience similarly casts doubt on the efficacy of sport as a means for promoting practical cooperation and political reconciliation between divided part-nations. In choosing sports suitable for promoting inter-Korean cooperation one criteria has been a team sport that both sides are reasonably adept at and which is popular within both countries. In reality, over the past four decades or so, that has usually come down to football, basketball and table tennis. Under the banner of "reunification," football and basketball matches were occasionally played between teams representing Pyongyang and Seoul or organizations within the two countries, ${ }^{66}$ but out of the three sports it has been table tennis and the memory of Sino-US "ping pong diplomacy" that have impinged on the popular and governmental - imagination the most. Yet, despite the precedent of the SinoUS breakthrough and the North's own "dry run" of using "ping-pong diplomacy" with Malaysia in 1973, the Korean usage of table tennis has failed to achieve lasting results. ${ }^{67}$

The events surrounding the 1979 Pyongyang tournament suggested that politics - or, more specifically, the lack of mutual trust - were sufficiently powerful to prevent breakthroughs in either inter-Korean or North Korean-US relations. The North deliberately downplayed any prospects of "ping-pong diplomacy" with the South after the latter hesitated to agree to the North's insistence on forming a unified team. Yet, the possible North Korean-US breakthrough scenario, which may well have been the North's main target anyway, never materialized either, in part because of the very way the North had treated the South. In 1991, after initial

66 For example, basketball games were played between Pyongyang and Seoul teams in 1999, 2003 and 2018. I am indebted to Prof. Lee Seok for this information.

67 North Korea had successfully leveraged a visit by a table tennis team to Malaysia in 1973 to encourage the process of establishing diplomatic relations with that country. While this could have provided inspiration for the North to repeat the strategy, both South Korea and the United States were a different order of magnitude as diplomatic targets in the North's worldview. I am indebted to Dr Hoo Chiewping, who is researching the topic, for the information about the Malaysian case. 
political contacts, the unprecedented and symbolically significant joint women's team victory at the WTTC was important, but even then a souring of inter-Korean political relations a few months later led to the abandonment of sustained sporting cooperation. Finally, the dramatic creation of a joint table tennis team in 2018 also served to become a false dawn, as the ongoing problems over North Korean denuclearization have stalled political progress which in turn impacted on inter-Korean sporting cooperation. As political dialogues between North Korea and the United States and between the two Koreas have faltered and then halted, so too have hopes been dashed that, for example, the two Koreas might bid to be co-hosts of the 2032 Olympic Games.

The frustrating attempts to ensure sustained sporting cooperation are a microcosm of the wider difficulties of promoting reconciliation within the inter-Korean relationship. Consequently, the dreams of sporting cooperation embodied in table tennis have frequently fallen victim to the whims and vagaries of political interactions. As such, rather than sport (table tennis) helping to promote political reconciliation, it has been politics that have driven or handicapped sports in the case of the divided Korean peninsula.

\section{References}

1. Berkman, Seth. A Team of Their Own: How an International Sisterhood Made Olympic History. New York: Hanover Square Press, 2019.

2. Bridges, Brian. The Two Koreas and the Politics of Global Sport. Leiden: Brill-Global Oriental, 2012.

3. Buzo, Adrian. The Guerrilla Dynasty: Politics and Leadership in North Korea. Boulder: Westview Press, 1999.

4. Cha, Victor D. Beyond the Final Score: The Politics of Sport in Asia. New York: Columbia University Press, 2009.

5. Choi, Daeseok. "Building Bridges: The Significance of Inter-Korean Sports and Cultural Exchange." East Asian Review, 14, no.4, (Winter 2003): 107115 .

6. Close, Paul, David Askew and Xu Xin. The Beijing Olympiad: The Political 
Economy of a Sporting Mega-Event. Abingdon: Routledge, 2007.

7. Clough, Ralph. Embattled Korea: The Rivalry for International Support. Boulder: Westview Press, 1987.

8. Foster-Carter, Aidan. Korea's Coming Reunification: another East Asian superpower? London: Economist Intelligence Unit, 1992.

9. Griffin, Nicholas. Ping-Pong Diplomacy: The Secret History Behind the Game That Changed the World. London: Simon \& Schuster, 2014.

10. Harrold, Michael. Comrades and Strangers: Behind the Closed Doors of North Korea. Chichester: John Wiley \& Sons, 2004.

11. International Table Tennis Federation (ITTF). "North \& South Korea to Join Forces at ITTF Korea Open.” Press Release. July 16, 2018.Accessed February 13, 2020. https://www.ittf.com/2018/07/16/north-south-korea-join-forcesittf-korea-open.

12. Jarvie, Grant. Sport, Culture and Society: An Introduction. London: Routledge, 2006.

13. Jhe, SeongHo. "North-South Sports Exchange and Peace on the Korean Peninsula." In Peace on the Korean Peninsula through Sports Exchange. Seoul: Sports Institute of National Unification, 2003: 159-170.

14. Jonnson, Gabriel. Towards Korean Reconciliation: Socio-Cultural Exchanges and Cooperation. Aldershot: Ashgate, 2006.

15. Kim Ilsŏng. Kim Il Sung: Works, Volume 30 (January-December 1975). Pyongyang: Foreign Languages Publishing House, 1987.

16. Kim Chŏngil. "On Popularizing Physical Training and Sport and Developing Sporting Skills Rapidly.” 19 May 1986. www.korea-dpr.com.

17. Lammer, Manfred. "The Olympic Games: A Bridge to Unification? German Experience and Korean Perspectives." In Peace on the Korean Peninsula through Sports Exchange. Seoul: Sports Institute of National Unification, 2003: 99-111.

18. Lee, Chaejin and Hideo Sato. U.S. Policy Toward Japan and Korea: A Changing Influence Relationship. New York: Praeger, 1982.

19. Lee, Jean H. "Ex-NKorean star recalls 'ping pong diplomacy'." San Diego Union-Tribune, July 12, 2012, www.sandiegouniontribune.com/sdut-exnkorean-start-rcealls-ping-pomg-diplomacy-2012jul12-story-html. 
20. Lee, Seok. "Becoming a Member of the Japanese National Football Team as a Korean: The 1936 Berlin Olympic Trials and Colonial Korea." In Sport in Korea: History, Development, Management, edited by Kwak Daehee, Ko Yongjae, Kang Inkyu, and Mark Rosentraub. London: Routledge, 2017: 31-44.

21. Lewis, Richard. "North Korea's Behaviour At The 1979 Ping Pong Championships Really Said It All.” Business Insider, May 12, 2014. https://www.businessinsider.com/ping-pong-in-north-korea-2014_5?IR=T.

22. Koh, Byungchul. "Unification Policy and North-South Relations." In North Korea Today: Strategic and Domestic Issues, edited by Robert A. Scalapino and Kim Junyeop. Berkeley: University of California, 1983: 264-308.

23. Mackay, Duncan. "Bach hails PyeongChang 2018 for its part in Korean peace process and promises IOC will continue to play role." Inside the Games, February 7, 2019, https://www.insidethegames.biz/articles/1075256/bach-hailspyongchanag-2018-for-its-part-in-Korean-peace-process-and-ptomises-iocwill-continue-to-play-role.

24. Martin, Bradley. Under the Loving Care of the Fatherly Leader: North Korea and the Kim Dynasty. New York: Thomas Dunne Books, 2004.

25. Merkel, Udo and Kim, Misuk. "Third time lucky!?: PyeongChang's bid to host the 2018 Winter Olympics - politics, policy and practice.” International Journal of the History of Sport 28, no.16 (November 2011): 2365-2383.

26. National Archives and Record Administration (NARA), United States, Department of State Electronic Telegrams, 1979.

27. National Unification Board. A White Paper on South-North Dialogue in Korea. Seoul, 1982.

28. Noerper, Stephen. "Tensions, Tests, and Drift." Comparative Connections, January 2018: 33-40. http://cc.pacforum.org/2018/01/tensions-tests-drift

29. Oberdorfer, Don. The Two Koreas: A Contemporary History. New York: Basic Books, 2001.

30. Oh, Kongdan. "The Problem and Promise of Inter-Korean Economic Cooperation." In Korea Briefing: Toward Reunification, edited by David R. McCann. New York: M.E. Sharpe, 1997: 25-48.

31. Ok, Kwang. The Transformation of Modern Korean Sport: Imperialism, Nationalism, Globalization. Seoul: Hollym, 2007. 
32. Pavitt, Michael. "North and South Korea abandon quarter-final clash to form unified team at ITTF World Championships." Inside the Games, May 3, 2018. https://www.insidethegames.biz/articles/1064646/north-and-south-korea-aban don-quarter-final-clash-to-form-unified-team-at-ittf-world-championships.

33. Pound, Richard. Five Rings Over Korea: The Secret Negotiations Behind the 1988 Olympic Games in Seoul. Boston: Little, Brown \& Co, 1994.

34. Shinn, Rinnsup. "North Korea: Squaring Reality with Orthodoxy." In Korea Briefing, 1991, edited by Donald Clark. Boulder: Westview Press, 1991: 85124.

35. Snyder, Scott. "South Korea's Olympic Gains." Council on Foreign Relations Expert Brief. January 26, 2018. https://www.cfr.org/expert-brief/southkoreas-olympic-gains.

36. Son, Keyyoung. South Korean Engagement Policies and North Korea: Identities, Norms and the Sunshine Policy. London: Routledge, 2006.

37. Sugden, John and Alan Bairner. Editors. Sport in Divided Societies. Oxford: Meyer and Meyer, 1999.

38. Takahashi, Kosuke. "When ping-pong diplomacy stirred Korea." Asia Times. May 17, 2012. http://www.asiatimes.com/asiatimes/Korea /NE09Dg01.html

39. The National Archives, United Kingdom (TNA), Foreign and Commonwealth Office records.

40. Trankos, Judith, and Bob Heere. "Sport Diplomacy: A Review Of How Sports Can Be Used To Improve International Relationships.” In Case Studies in Sport Diplomacy, edited by Craig Esherick and Robert E. Baker, 1-15. Morgantown,WV: FiT Publishing 2017.

41. Wagg, Stephen and David L. Andrews. East plays West: Sport and the Cold War. London: Routledge 2009.

42. Xu, Guoqi, Olympic Dreams: China and Sports, 1895-2008. Cambridge: Harvard University Press, 2008.

43. Yonhap News Agency. Korea Annual 1992. Seoul, 1992. 


\section{〈Abstract〉}

\section{Driver of Peace? Ping-Pong Diplomacy on The Korean Peninsula}

Brian Bridges

Amongst the various examples of sport influencing politics, the role of table tennis in facilitating ground-breaking connections between the United States and the People's Republic of China - the so-called "ping-pong diplomacy" of the early 1970 s - is probably the most-cited. However, the use of this sport has not been confined to those two major powers; rather, there have been attempts to utilize it to bring about reconciliation to the long-standing inter-Korean enmity. However, in the case of divided nations (such as on the Korean peninsula), sport takes on the nature of not only a competitive rivalry but also an overtly political struggle for legitimacy. Politics drive sport, not the other way around. By utilizing unpublished British and American archives and by examining the cases of the World Table Tennis Championships held in Pyongyang in 1979 and Japan in 1991 as well as the post-PyeongChang Winter Olympics events, the inflated expectations and ultimate limitations of using sport in general-and table tennis in particular - as a utilitarian force for reconciliation between the two Koreas are shown.

Keywords: table tennis, North Korea, South Korea, world championships, reconciliation 
〈국문초록〉

\section{평화의 동력? 한반도의 핑퐁외교}

Brian Bridges (The Education University of Hong Kong)

스포츠가 정치에 영향을 미친 여러 사례들 중에 가장 많이 언급되는 케이스는 아마 도 1970 년대 초반 소위 핑퐁외교로 불리는 미국과 중국간 관계의 획기적 개선을 촉진 한 탁구의 역할일 것이다.

그러나 탁구의 정치적 이용은 두 강대국에 국한되었던 것은 아니었다. 오히려 오랜 남북간 대치상황에 화해 분위기를 조성하기 위해 이 스포츠를 이용하고자 한 시도들이 더 많았다.

한반도와 같이 분단된 국가들의 경우에 스포츠는 경쟁적인 라이벌 관계뿐만 아니라 공공연히 정치적 정당성을 획득하기 위한 투쟁의 속성을 갖고 있다.

따라서 정치는 스포츠를 일정한 방향으로 추동하며 그 역은 성립하지 않는다.

이 논문에서는 미공개의 영국과 미국 자료들을 활용하고 평창 동계 올림픽 이후 이 벤트들 뿐만 아니라 1979년 평양과 1991년 일본에서 열린 세계탁구 선수권 대회의 사 례들을 분석한다. 이를 통해 남북간 화해를 위한 실용적 동력원으로써 스포츠-특히 탁구-의 이용이 야기한 과잉기대와 궁극적 한계를 드러내고자 한다.

주제어: 탁구, 남북한관계, 세계선수권대회, 남북화합 
